Висновки. Ефективна профілактична робота первинної ланки надання медичної допомоги з особами, які відносяться до групи високого ризику розвитку інфаркту міокарда дозволить знизити рівень його розвитку та зменшити рівень його тяжких медико-демографічних та соціальних наслідків.

Слабкий Г.О., Миронюк І.С., Білак-Лук’янчук В.Й.

\title{
Спільні задачі первинної медико-санітарної допомоги та системи громадського здоров'я по збереженню здоров'я населення
}

\author{
ДВНЗ «Ужгородський національний університет», м. Ужгород, Україна
}

Мета - розробити та представити спільні задачі первинної медико-санітарної допомоги та системи громадського здоров'я по збереженню здоров'я населення.

Матеріали та методи. Матеріалами дослідження стали чинні законодавчі акти України з питань організації діяльності первинної медико-санітарної допомоги населенню та системи громадського здоров'я. При виконанні роботи використано методи контент-аналізу та системного підходу.

Результати. В Закарпатській області сформована система первинної медико-санітарної допомоги та формується система громадського здоров'я. Відповідно до чинного законодавства України основною задачею первинної медичної допомоги є в тому числі профілактика як інфекційних так i неінфекційних захворювань, формування у населення здорового способу життя, виявлення захворювань на ранніх стадіях розвитку та проведення роботи з мінімізації індивідуальних факторів ризику розвитку захворювань та їх ускладнень. Головна задача системи громадського здоров'я полягає у збереженні та зміцненні здоров'я населення шляхом промоції здоров'я, моніторингу та реагування на надзвичайні ситуації в сфері громадського здоров'я, формування у населення відповідального ставлення до особистого здоров'я. В досягненні мети відміною в організації роботи цих вказаних ланок охорони здоров'я населення $є$ те, що первинна ланка медичної допомоги здійсьнює свою діяльність на індивідуальному, а система громадського здоров'я на рівні громад та популяційному рівні. Комплексне об'єднання їх зусиль дозволить координувати напрямки та заходи діяльності та підвищити ï ефективність. 3 метою координації зусиль системи первинної медико-санітарної допомоги та системи громадського здоров'я рекомендується розробити перспективний план сумісної робити названих структур та детальні комплексні заходи як на рівні регіону так і на рівні кожної адміністративної території регіону враховуючи медико-демографічні, соціально-економічні та екологічні особливості кожної території.

Висновки. Сумісна робота первинної ланки надання медичної допомоги та системи громадського здоров'я забезпечить підвищення рівня профілактичної роботи та зміцнення здоров'я населення Закарпаття.

\section{Забезпечення населення гірської та передгірської зони Закарпаття первинною медико-санітарною допомогою}

\author{
ДВНЗ «Ужгородський національний університет», м. Ужгород, Україна
}

Мета - дослідити рівень забезпечення населення гірської та передгірської зони Закарпаття первинною медико-санітарною допомогою.

Матеріали та методи. При проведенні дослідження використано дані галузевої статистичної звітності по Закарпатській області за період 2019 рік. В ході дослідження використано статистичний метод та метод структурно-логічного аналізу.

Результати. Закарпатська область характеризується наявністю трьох географічних зон проживання населення: 